\title{
The discursive cultural representations of Gentiles: A contextual approach using migration theory
}

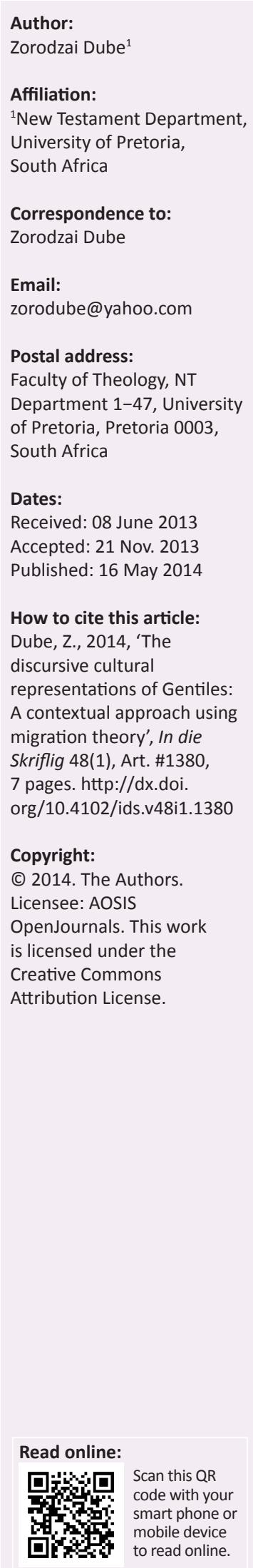

How are social boundaries created and how are they maintained? To an extent, the way people look, dress and talk demarcates cultural markers that distinguish them from others - hence, giving them a sense of self-categorisation and self-identity. However, with time such collective identity might need readjustment when people from another culture become insiders and neighbours within the perceived social boundaries. Regarding this, James Dunn noted that a challenge of social cohesion between the Jews and the Gentiles existed during the 1st century, necessitated by the conversion of Gentiles to Christianity. In response, to keep their exclusive collective identity, the Jews demanded that the Gentiles observe Jewish law. This article develops Dunn's view that the observance of Jewish law provided implicit social exclusion strategies towards the Gentiles. However, Dunn did not elaborate further concerning the strategies upon which Gentiles were excluded. As contribution to fill that void, this article drew on strategies of inclusion and exclusion from the analogy of migration in South Africa and elsewhere.

Die omvattende kulturele uitbeelding van heidene: 'n Kontekstuele benadering met behulp van die migrasieteorie. Hoe word sosiale en kulturele grense geskep en onderhou? Tot 'n mate bewerkstellig die manier waarop mense uiterlik voorkom, aantrek en praat kulturele kenmerke wat sekere groepe van ander onderskei, en verleen so aan hulle'n bepaalde identiteit en klassifisering. So 'n gemeenskaplike identiteit moet mettertyd aangepas word as mense van ander kulture met ander gebruike deel word van die binnekring. In hierdie verband merk James Dunn op dat, in die eerste eeu na Christus, die Jode en heidene aangespoor is tot 'n samehorigheidsgevoel wat deurdie bekering van heidene tot die Christendom genoodsaak is. In reaksie hierop het die Jode aanvanklik verwag dat die heidene die Joodse wet moes nakom. Hierdie artikel bou op Dunn se siening, naamlik dat die onderhouding van die Joodse wet sosiale strategieë ontwikkel het wat die heidene onvoorwaardelik uitgesluit het. Dunn brei egter nie verder oor die sogenaamde strategieë uit nie. In hierdie artikel word gepoog om hierdie leemte aan te vul deur middel van 'n vergelyking met kontemporêre migrasie in SuidAfrika en die strategieë van insluiting en uitsluiting wat bespeur word in sulke kontekste, te verdiskonteer.

\section{Introduction}

By the late 1st century, the relationship between the Jews and the nascent Christian movement became further strained, and negative labeling became more pronounced against the synagogue and the Jews (Hays 1996). Some Pauline letters, including Matthew's and the John's community, exemplify this development. From the inception of Christianity after the death of Jesus, a seeming steady and gradual hatred developed, which culminated in the excommunication of Gentiles from the synagogue by the Jews, after the so-called Jamnia meeting around 90 CE (Puskas 1989). Several factors can be pointed out as reasons that exacerbated the conflict - amongst them the theological confessions that referred to Jesus as Messiah and the coming of the Gentiles into predominately Jewish churches (Puskas ibid). Paul's letter to the Philippians (Phlp 3:2) is an

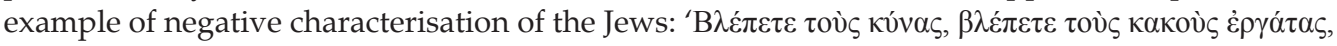

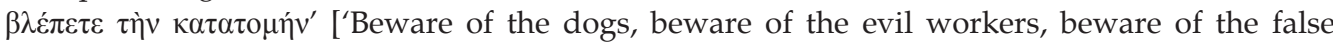
circumcision']. Amongst the Jews a dog is an unclean animal, and to juxtapose an unclean animal with circumcision shows the level of disdain against the Jews who use cultural markers to express themselves. Regarding this, Hays (ibid) remarked that:

By the late first century, the success of the preaching mission to Gentiles and the simultaneous relative failure of the mission to the Jews had begun to create a major crisis. There were 'too many Gentiles to few Jews', in this new messianic community which therefore was in danger of losing its Jewish identity altogether particularly in light of the community's fateful decision not to require Gentile converts to be circumcised and keep the Jewish dietary laws. (p. 28)

This article builds on Dunn's insight (2005) that the Jews used the law to discriminate against the Gentiles and to keep them out of the synagogue and it developed from the realisation that 
there is a lack of insight into the strategies of social exclusion. Besides a couple of references in New Testament texts such as Romans, Matthew and John, the challenge is exacerbated by a lack of historical data. Furthermore, issues that relate to segregation and an embedded negative attitude towards outsiders are understood by observing bodily gestures, which is impossible to resuscitate given the historical chasm between our time and the past. No records exist to allow us to explore such a discussion.

This contribution utilises recent insights from migration studies, exploring various forms of social exclusion to provide plausible insights into this discussion. There is a possibility that reservations might be raised regarding how migration, a recent development, can shed light and act as a model of events that happened during the 1st century. However, migration theory is indeed used as a heuristic, analogical tool. The success of this endeavour must be judged on the basis of plausibility (and not chronology) of this analogy and the questions that are raised to illuminate the discussion.

This article utilises two theoretical perspectives. Firstly, a social scientific method is been utilised to draw models or analogies (in this case, migration) that shed light into the social dynamics of inclusion and exclusion between the Jews and the Gentiles. Secondly, to complement the migration perspective, this article uses the theory of representation developed by Hall (1997) to tease out the discursive cultural strategies that represent outsiders as dirty, unwelcome and filthy. Using these two perspectives, the article managed to go beyond merely stating the existing conflict between Jews and Christians. As contribution, the aim is to explore indelible inscriptions that categorise outsiders as filthy based on their accent, expressions, dressing and gestures.

\section{Comparing the dynamics of social exclusion with migration}

Before continuing with the discussion, contentious issues need to be addressed.

\section{How plausible is it to use migration as a model or analogy to compare the dynamics of social exclusion?}

The analogical method is a common method used in academic disciplines such as archaeology and anthropology. Lately it has been used in biblical studies as a heuristic tool to develop inferences about the unknown past. It functions in areas that lack sufficient historical records to provide an explanation about the past. The American anthropologist, Robert Ascher (1961), states that the analogical method was introduced into the archaeological field during the era of classical evolution ideology. Classical evolution ideology believes that human communities developed from primitive societies to modern technological societies. As a heuristic tool, the analogical method argues that less developed societies provide information about the early phases of human history ${ }^{1}$ (Gould \& Watson 1982).

1.Archaeologists and anthropologists have studied groups such as the Tasmanians, Australian Aborigines, Bushmen and Eskimos.
However, in agreement with Peter Craffert (2001), this article acknowledges that the method has practical problems of conflating data from different cultures during the process of comparing cultural traits (Craffert ibid). Charlse W. McNett (1979) further notes that a possibility of anachronism might occur since the method has no clear criterion for judging the compatibility of analogies.

The analogical method has two types of approaches: the direct-historical approach (emic) and the comparativeinferential analogy (etic). The direct-historical approach, also known as the folk culture approach, uses data from geographic sites that are characterised by long-term cultural continuity (inside), whilst the comparative-inferential analogy derives analogies from comparable situations with no cultural or historical links (outside; Gould \& Watson 1982).

Most analogies that have been used by biblical scholars such as Bruce Malina, are from the Mediterranean region - an area reflected in the Bible. Accordingly, these analogies are directhistorical approaches. Analogies from the direct-historical approach focus on the continuity between the present communities and their link with past societies (McNett 1979). ${ }^{2}$ Researchers use the historical approach in cultural areas with historical continuity, for example in parts of the Middle East, where the contemporary process of brewing beer is believed to have a similar pattern to comparable activities in the past. ${ }^{3}$ The American anthropologists, Richard Gould and Patty Watson, believe that direct-historical analogies are stronger than comparative approach analogies, because they have the advantage of providing testable and a priori strong analogies (Gould \& Watson 1982). Direct-historical analogies have the advantage of coming from present cultural activities, directly linked to past institutions. This makes them more likely to be analogous in multiple ways, to past activities, institutions and materials than analogies derived from regions with no historical link (Gould \& Watson ibid).

This article uses migration as an indirect analogy. Analogies derived from the comparative-inferential approach focus on two things: firstly, on the comparable aspects between an analogue and the subject of discussion (McNett 1979), ${ }^{4}$ and secondly, on the functional relationship of the parts

2.The focus of the folk-cultural approach or direct analogy, is on the region and how it provides continuity with the prehistoric society found in the same region. This approach is supported by what has come to be known as the 'California school', aproach is support which was led by Alfred Kroeber in the early 1940s. This approach involves gathering data from many traits of every culture within the region. Similarities are documented to measure coefficients and intercultural relationships. This allows observations of clusters of closely related cultures. The aim was to reconstruct the
history of the cultures involved (see McNett 1979:42).

3.Robert Ascher (1961:318) calls this an evolutionary approach. This approach is declining in its usage due to earlier abuses where scholars randomly and anachronistically projected everything they found into the past - even analogies that were drawn from regions far from where the article was done. Sometimes other cultures, which were lagging in technological advancement such as the Australian Aborigines, were studied with bias. This article agrees that the earlier usage of this approach was characterised by bias and prejudice with regard to certain cultural groups that were seen to be less technologically developed.

4.George Peter Murdock led this school of thought in 1937. Murdock has been credited with collecting data froma worldwide sample of cultures and testing the association with various statistical measures. Some of his works are found in coded files such with various statistical measures. Some of his works are found in coded files such as the 1957 World Ethnographic Sample and the Ethnoglogue traits of various cultures in the world, grouping their similar chacteristic traits. The data collected is put in similar categories. This process is called the standard crosscultural sample (SCCS) and ensures that each cultural type is represented in the sample, hence representing the cultural universe (see McNett 1979:42). 
of a specific culture rather than their chronological history (McNett ibid). In other words, the focus is on comparable aspects at a specific time and space. This is important to remember when evaluating the plausibility of migration as an analogy.

Though scholars prefer the historical approach, comparative analogies are equally useful, because analogies are on the same logical footing as testable hypotheses. This means that all analogies are comparative methods, because they search for plausible inferences (Gould \& Watson 1982). As Douglas E. Oakman (2001:103) concludes, all analogies perform a similar function as acceptable interpretations, because they all need proof. In fact, more caution must be exercised when using direct analogies, because researchers are tempted to accept a contemporary population as living prehistoric people in every mode of their behaviour (Gould \& Watson ibid:360).

\section{Movement, boundaries and belonging}

This article uses migration as an indirect analogy (a heuristic tool), focusing on possible comparative aspects and plausible questions between the two. As a heuristic comparative tool, migration theory provides a fertile ground and a platform to tease out issues that relate to movement, boundaries and belonging, which will be further discussed using Hall's theory of representation, and to explore questions and issues that arise when two incompatible cultures mix. Migration theory discusses various issues, but always from the following three facets: movement, boundaries and belonging (Delanty 2008). Those who discuss movement focus on factors that cause migration, whilst discussions that centre on boundaries raise issues regarding conflict and segregation. Inquiries into the area of belonging discuss issues relating to challenges of acceptance and strategies taken to make an outsider become an insider, which is a complex process that requires the surrendering of one's previous cherished identities such as language or status.

Firstly, regarding movement, the Gentiles' conversion to Christianity can be regarded as a movement, because, like migration, they responded to a felt need. Migration studies start from the assumption that push and pull factors cause people to migrate in search of an alternative home (Knudsen 2009). From this perspective, migration studies may help to investigate ways in which the Gentiles responded to Christianity from a sociological viewpoint.

Secondly, regarding boundaries, outsiders can be accepted as equal members without being forced to learn the language and cultural practices of people where they sojourned. The coming of Gentiles into what used to be a predominately Jewish culture necessarily caused social friction concerning identity. A social anthologist, Mary Douglas (1966), observed that when penetrated from outside, communities tend to strengthen their external boundaries to keep foreign intruders at bay. The coming of the Gentiles into the Christian faith may have created the question of social identity. In this regard, Paul's attitude of condoning lack of circumcision and lack of keeping the Jewish law, contradicted with the cultural practices of many Palestinian Jews (Pattee 1995). This is a likely possibility, since 1st-century Christianity expressed a Jewish outlook, having been born within the cradles of Judaism (Bronson 1967). To such cultural insensitivity, the Jews began with a relaxed attitude to their neighbours (especially the god-fearing), but later, due to the increase of Gentiles into the synagogue, a hostile attitude towards non-Jews developed (Dunn 2005). Using migration theory, this article suggests that the question whether the Gentiles must keep the Jewish law may be understood similarly as the concern over the exclusion or inclusion of outsiders in migration. As analogy, migration being an observable phenomenon may shed light regarding social boundaries.

Thirdly, regarding belonging, as people migrate they inevitably express their cultural baggage, including religion, language and dress codes. Outward cultural identity markers are the initial observable aspects according to which people are defined as either in- or outsiders. Regarding this, migration theory may help to explore how once seemingly strange and distant cultures have become neighbours - a situation that inevitably caused the exclusion of outsiders based on cultural or ethnic differences.

Using these three comparative lenses, migration as an analogy may help to explore the following questions:

1. What challenges do outsiders face to be recognised as insiders?

2. How were social boundaries maintained?

3. What negative labels or representation might be used to keep the outsiders distant?

Migration may be used as a tool or analogy to relive the lost dynamics concerning how social boundaries might have been maintained during the 1st century.

\section{Paul and the Jewish law: Scholary views}

The focus now shifts to the social dynamics of inclusion and exclusion during the 1st century.

Pervasive throughout most of Paul's letters is how the Gentiles were excluded and often regarded as outsiders by the Jews. A clear example is the mini-drama that happened at Antioch when Peter and Judean Jews refused table fellowship with the Gentiles. Hans Betz (1979), in his famous Hermeneia series, commented that the issue arouse, because the Jews created a subgroup, separating themselves from the rest of the Gentiles whom they regarded as the unclean. To the Jews, issues regarding cleanliness and uncleanliness were not only hygienic categories, but also social issues of identity (Douglas 2010). Frederiksen (2002) clarifies that: firstly, the issue of gentile inclusion in the synagogue was not a problem, because most god-fearers (those who were not fully converted to Judaism) were not coerced to fulfill Jewish laws. However, 
as the number of Gentiles who flocked into the synagogue increased, the Jews created a separate subgroup at Antioch. This raised questions regarding the level of observance of the Jewish law (Dunn 2005). Mark Nanos (2002) commented that the Jews could not tolerate sitting at the same table as the Gentiles who were either guests or proselytes. They could not treat the Gentiles (Nanos ibid):

... as though these Gentiles and Jews were equals, although these Gentiles were not Jews, in fact, they were - in principle - not even on their way to becoming Jews, meaning proselytes. (p. 282)

Clearly, Paul converted the Gentiles, disregarding Jewish cultural markers and in many instances even disparaging

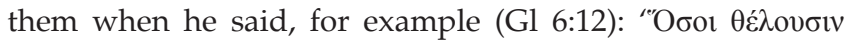

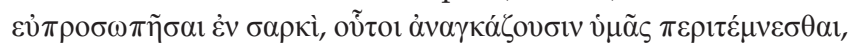

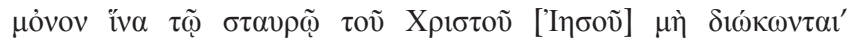
['Those who desire to make a good showing in the flesh try to compel you to be circumcised, simply so that they will not be persecuted for the cross of Christ']. The Greek word $\varepsilon v j \pi \rho \circ \sigma \omega \pi \tilde{\eta} \sigma \alpha$ [ [to make a good showing] is important to unpack cultural conflict. Paul's accusation is made in the context of circumcision, but it also includes other strategies in which the law was used as identity marker, aimed at excluding those who did not share such bodily imprint. Paul referred to how the law was carried out as identity marker as 'the works of the law', which included several practices such as questions regarding fellowship, rules regarding food, marriage, clothes and circumcision. Circumcision, though not overt, was a central identity marker amongst Jewish men - a practice that stretched as far as the time of Abraham in the formative years of the nation of Israel. From this perspective, doing the 'works of the law' was not mere religious duty, but social identification. 'I am a Jew and I conduct my life in this manner' would be the attitude presiding over the conduct and assumptions about outsiders.

When discussing the role of the law, a theological conservative stance, known as the Lutheran school, has been maintained historically (Dunn 2005). Based on the theological view, the 'works of the law' is understood as the legal requirements observed to fulfill the law. Based on the interpretation of Paul's theology in Romans, Paul felt the 'the pangs of conscience', referring to his inability to live the demands of the law. In Romans 7:18, Paul remarked: 'For I have the desire to do what is right, but not the ability to carry it out.' As a result, he lamented (Rm 7:24): 'Wretched man that I am! Who will deliver me from this body of death?' Paul discovered that the law was insufficient to deal with his inner guilt and then arrived at the conclusion that people are saved by grace through Jesus Christ, and not by the 'works of the law' (Rm 3:23; Sloan 1991).

Prominent New Testament scholars such as Bultmann and Käsemann, share this view, proposing that Paul's 'justification by faith' militated against the stagnant and the unreformed 1st-century Judaism (Dunn 2005). Today, this perspective still commands a substantial following amongst evangelical theologians, though other scholars regard it as a defunct view. This article values this position, because it juxtaposes salvation with sin. However, it is limited in that it regards sin based on a modern, individualistic perspective - as an inner conscience. From our knowledge of the Mediterranean culture, sin had a horizontal dimension rather than an inner conscience or inability to live the law. In agreement, E.P. Sanders (2009) accused the position for confining Paul's discussion about the law to issues of sin and guilt. Sanders was the first to bring the discussion concerning the law to the realm of sociology by suggesting that 'the works of the law' was 'covenantal nomism' - a conviction that, by keeping the law, the Jews would guarantee their favoured social status with God (Sanders 2009). Sander's position formed the landmark of what has become known as the 'new perspective on Paul'. The position influenced various other perspectives, including that of Dunn.

This article builds on Sanders' and Dunn's view, though with much bearing on Dunn's perspective. According to Dunn (2005), the 'works of the law' should be understood as cultural and religious identity markers. Amongst them being circumcision, dietary rules, dressing and rules regarding fellowship, which defined and distinguished the Jews from the Gentiles. In this regard, the 'works of the law' were overt, that is, other people were able to see them (though circumcision was only performed on men and was not easily noticeable). Thus doing the 'works of the law' was intrinsically intertwined with Jewish identity formation. The observance of the Torah (circumcision, Sabbath, purity and dietary laws) ensured social boundary markers that excluded non-Jews.

\section{How were visible identity markers used to enforce identity and distinguish outsiders from insiders?}

Scholars such as Sloan (1991), criticises Dunn's sociological view as a misreading of Paul's understating of the 'works of the law'. Sloan (ibid) argues that the 'works of the law' refers to additional requirements imposed by the Jews, and that Paul attacked the Jews for elevating the practice of circumcision and other legalistic practices, whilst disregarding the rest of the law (Schreiner 1991). According to Sloan, Paul frequently juxtaposed the 'works of the law' to salvation. Sloan blames Dunn for seemingly reducing Jesus' sacrificial atonement to salvation against bad attitudes such as racism (Sloan ibid). Sloan's thesis is persuasive but unconvincing, since he does not explain what he means by 'obeying the law'.

Sloan seems to read Paul's debate with the Jews as centred on the right interpretation of the law. The law was at the centre of the debate, but it was not the end. The real problem was broadening the social boundaries to include the outsiders the Gentiles. Largely, this article concurs with Eric Stewart's (2011) conclusion that:

\footnotetext{
... the problem with Peter and the 'rest of the Judeans' then, is not that they used to eat food that was impure for Judeans, but they used to eat with Gentiles as equals and had ceased from that practice. (p. 7)
} 
Hence, Peter is behaving inconsistently 'by first eating with the Gentiles and then withdrawing from table fellowship' (Stewart 2011:3). From this perspective, Paul's 'justification by faith' circumvents the strict landmarks erected due to the observation of the law to arguing that faith in Jesus qualifies both the Jews and the Gentiles to be one before God. As mentioned earlier, the challenge is how to tease out strategies of social exclusion given the time and distance between now and the 1st-century audience, and this article proposes migration as analogy to tease out these dynamics of social exclusion between the Jews and the Gentiles.

\section{Discursive cultural representation of the Gentiles using migration theory}

\section{Movement}

The problem of social cohesion started with the conversion of Gentiles and their coming into the same social space (synagogue) as the Jews. This aspect of migration needs to be discussed with caution, because the Gentiles did not travel long distances like contemporary migrants. However, this aspect is raised from the perspective of crossing social boundaries since 'movement' suggests boundary crossing it implies the crossing of physical and cultural boundaries. In the case of the Gentiles, they did not cross geographic boundaries, but cultural boundaries (Delanty 2008). The American sociologist, Charles Tilly (2005:131), defined social boundaries as social strategies that interrupt, divide, circumscribe, or segregate distributions of population or activity within social fields'. For the Jews and Gentiles, the problem of social conflict rose due to the coming of the Gentiles into the synagogue. This echoes contemporary questions regarding the collapsing of once strong demarcated social boundaries due to migration and globalisation. It raises questions regarding the pull and push factors, in addition to the inevitable challenge of acceptance.

Contemporary migration may give us enough raw materials to understand the issues around movement and acceptance. Studies indicate that between 2.5 and 12 million people travel to South Africa each year (MacDonald \& Zinyama 2000) from neighbouring countries such as Zimbabwe, Botswana, Zambia and Mozambique, and as far as Tanzania, Somalia, Kenya, Nigeria and Ghana. There are skilled and also unskilled people amongst them. It is important to note the way that the media represent migrants as unwelcomed people who contaminate and disturb local people's cultures. MacDonald and Zinyama (ibid) pointed out that immigrants are depicted as 'rootless drifters', or as an uncontainable natural disaster (e.g. 'flood of illegal aliens', Peberdy \& Crush 1998).

\section{Ethnicity}

Ethnicity may be used as lens to unpack the Jews' hostility towards the Gentiles. Swedish scholar Knudsen (2009) explored this argument, noting that an anti-immigrant stance is associated with national identity and is characteristic of people who want to keep their identity by maintaining clear boundary markers. Knudsen noted that strong attachment to nationality is likely to develop into the exclusion of foreigners, and individuals with strong national feelings grow a negative attitude towards foreigners and display a strong ethnocentrism. Recent migration studies reveal that the level of segregation against the outsiders is 'pervasive, diffuse, frequently paradoxically' (Delanty 2008). From his studies of migration, Delanty noted that the othering of outsiders is a confluence of racism and xenophobia, expressed through clandestine phrases such as 'protecting jobs' and 'concerned about welfare benefits' to 'cultural incompatibilities or differences', 'lack of cultural competence', 'they do not want to integrate' and 'they are not tolerant'.

The above may further illuminate studies that the Jews anchored their segregation of outsiders on the symbolic notion of ethnicity (Dunn 2005). Regarding the clandestine way in which the law was used to keep the Gentiles out of fellowship, Eric Stewart (2011) explains that at Antioch the Jerusalem delegation was not prepared to accept Gentiles who were not full converts. This may be interpreted as fear of an outsider. To Paul, this incident was an eye-opener concerning the implication of the theology based on justification by faith. This article views the segregation of others based on not being fully converts as similar to clandestine strategies through which migrates are not tolerated based on ethnicity.

\section{The attraction of Christianity}

Similarly, several factors may have acted as pull and push factors for the Gentiles to convert to Christianity. Meeks (1993) observed that a once hated and insignificant sect became attractive and later (in the 4 th and 5th century) a religion of the Empire due to several factors:

1. Firstly, the 1st-century Christians presented themselves as an alternative household and kingdom, calling each other 'sister' and 'brother'. Those who converted to the new religion were supposed to learn the egalitarian practices of sharing and new kinship. This aspect, according to Meeks (1993), attracted the poor and the outsiders who found a new home in Christianity. Baptism was instituted as the rite of passage, dramatising the separation from the previous life to becoming a 'sister' or 'brother' of those who are God's children. Meeks (ibid) noted that reminders of the boundaries between the old world and the new are a constant element in early Christian moral exhortation: 'You were ... but now you are.'

2. The second attraction was the otherworldly aspect of the movement. Meeks (1993) noted that early Christians viewed themselves as the 'third race' - neither Jews nor Greek, but an organised body of immigrants, resident aliens whom Paul in Philippians referred to having their commonwealth in heaven and not on earth (Phlp 3:20).

3. Thirdly, Christians were known for being morally responsible. Even during the 2nd century, after torturing Christians, Pliny (governor of Bythinia) wrote to Emperor Trajan that Christians 'bind themselves by oath to abstain from theft, robbery, and adultery, to commit no breach of trust and not to deny a deposit when called upon to restore it' (Meeks 1993). 


\section{Boundaries}

The encroaching of outsiders unconsciously forces the host communities to draw and strengthen their internal and external boundaries. Here are some local examples of how boundary markers are erected:

1. In South Africa, bodily marks can be seen as boundary markers that distinguish the locals from foreigners.

2. The Zulus are physically recognisable by small tattoos on their cheeks, which are inscribed at birth and culturally understood as helping to prevent the child from weeping. Equally, circumcision done to young boys is also a crucial bodily marker for a Zulu boy.

3. Skin colour is also a distinctive marker in South Africa, as most black people from the rest of the continent tend to have a darker skin and leaner bodies, whilst some South Africans have bigger body mass and lighter skin. However, caution must be exercised here since some distinctions tend to be arbitrary.

4. Language is mostly used as the immediate boundary marker. South African media coined the pejorative 'Makwerekwere' to refer to an outsider who is unintelligible. During the xenophobia attacks in South Africa, language was the immediate sign that one was a foreigner.

The above strategies may further explain how the Jews evoked a self-imposed notion of superiority, based on their relationship with Yahweh, as a boundary marker.

Tannaitic sources, for example reflect the views of scribes and sages of how they regarded themselves as God's elect (Loewe 2008). The Jews believed in a monotheistic, universal Creator who has shown particular favour for Israel because of their faithfulness in keeping the law. The Gentiles defaulted in their keeping of the law and, as such, Simon ben Yohai could recommend himself to God, saying: 'God am I over all who come into the world, nevertheless with my people Israel alone have I uniquely associated my name' (Loewe ibid). In terms of perception, the entire gentile world serves a constant reminder for the Jews to keep their special favoured status.

In addition, the Jews had social boundary markers through the practice of circumcision and food rituals. The requirement at Antioch that the Gentiles must be circumcised in addition to observing the Jewish law, implicitly unveils stereotypes associated and imprinted on the body of Gentiles. These bodily stereotypes are audible from Paul's description of

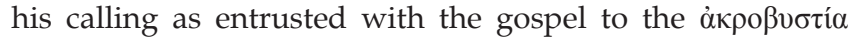
[uncircumcised]. This means that the Jews see circumcision as an important distinctive marker from the Gentiles. In this context, the uncircumcised gentile flesh carried a pejorative stigma as the 'other'. As Lee (2005:23) would argue: 'The Gentile "flesh" provides sufficiently a vivid illustration of the way in which Jews would develop their own correlation concepts by relating to a physical attribute or feature.' The circumcision mark was also embedded with the most crucial ideology: 'In the perception of most devout Jews simply lacking the mark of covenant and are, ipso facto, outside the sphere of the elect of God' (Lee ibid:98).

\section{Belonging}

The concept of belonging includes the issues of negotiating one's acceptance. The story of Peter at Antioch seems to show how people negotiate their belonging depending on what Tilly (2005) calls 'incentive shift'. Before the arrival of other Jews, Peter could be regarded as an outsider being a lonely Jew amongst Gentiles. Peter had no problem indulging with Gentiles. However, with the arrival of fellow Jews from Jerusalem, Peter became an insider and suddenly demanded that the Gentiles observe certain Jewish laws. Tilly (ibid) explains that social boundaries can sometimes be accentuated whilst at other instances relaxed, based on what he calls 'incentive shift', meaning that people do certain things, not because they like it, but to maximise their chances of survival.

Tilly's (2005) view may reveal that, whilst antagonism was visible in some places, Gentiles and Jews could indeed interact in other instances. Furthermore, Tilly's (ibid) view can be used to argue that, in many instances, outsiders can compromise on some of their strong identities in order to be accepted by the larger group. This sheds light on the pressure that the gentile Christians faced. Acts 16, for example, reveals that:

Paul wanted Timothy to go with him, so he took him and circumcised him because of the Jews who were in those places, since they all knew that his father was a Greek. (Ac 16:4)

Equally, the entire compromise made at the so-called Jerusalem council (Ac 14) reveals the challenge that the Gentiles endured to be accepted.

\section{Conclusion}

How far does migration as an analogy help to reveal the dynamics of social inclusion and exclusion? This article began with the realisation that an anagy is a comparative heuristic tool that functions as a plausible inference. The article was necessitated by a statement from James Dunn that the Jews practiced the law as a means to segregate nonJews from the synagogue, giving the assumption that what was known as the 'works of the law', were performative actions, visible to the onlookers. In summary, being Jewish was mostly a performative identity. Based on this, the onlookers would applaud the actions and identify with certain actions as identity markers. The implication from the publicly recognised actions was that outsiders (in this case the Gentiles) were visibly seen from their failure to perform certain cherished actions such as food rituals or rules regarding association. The challenge is to unpack the strategies of social segregation, given geographical and cultural differences.

To attempt this mammoth task, the social scientific approach to the study of the Bible employs what is called 'analogies', 'types' or 'models' drawn from contemporary situations based on their ability to imitate the unknown situation. In this case, analogies are neither imposed, nor randomly 
selected, but they are approved based on the ability to perform inference regarding dynamics of the unknown past.

How plausible is migration as an analogy or inference? Migration is a broad topic and has been discussed from three perspectives, namely movement, boundaries and belonging. This article used these facets as comparative lenses. Largely, migration gives insight regarding the treatment of outsiders, because the analogy sheds light on issues concerning dynamics of insider-outsider relations. Comparatively, regarding movement, migration studies reveal that when people move, they implicitly cross geographic and social boundaries. In the case of Gentiles converting and coming to the synagogue, they crossed social boundaries, where they were expected to know the Jewish law. In addition, migration tells us that the coming of outsiders is not always a welcome development. Instead, communities tend to resist outside infiltration, thereby keeping their internal ethnicity and boundaries. In this case, the coming of the Gentiles was received with hostility, because Gentiles had different cultural beliefs.

Migration also helped to tease out strategies of internal and external boundary control. Using insights from migration, this article observed that resistance can be overt or subtle. In the case of the Gentiles, especially from the story of Peter, it was sometimes hostile, but sometimes collegial, depending on the 'incentive shift'. Importantly, the article shows that issues of cultural difference produce social friction, but communities do not always experience antagonism. It can be postulated that, with regard to the Jews and the Gentiles, conflict mostly arose where issues of collective identity were under threat. In most other cases, Gentiles and Jews had common ways of identification.

\section{Acknowledgements \\ Competing interests}

The author declares that he has no financial or personal relationship(s) that may have inappropriately influenced him in writing this article.

\section{References}

Ascher, R., 1961, 'Analogue in archaeological interpretation', Southern Journal of Anthropology 17, 317-325.

Betz, H.D., 1979, Galatians: A commentary on Paul's letter to the churches in Galatia, Fortress Press, Philadelphia, PA.
Bronson, D., 1967, 'Paul, Galatians and Jerusalem', Journal of American Academy of Religion 35(2), 119-128. http://dx.doi.org/10.1093/jaarel/XXXV.2.119

Craffert, P., 2001, 'An exercise in the critical use of models: The "goodness of fit" of Wilson's sect model', in J. Pilch (ed.), Social scientific models for interpreting the Bible: Essays by the context group in honor of Bruce J. Malina, pp. 21-46, Society of Biblical Literature, Atlanta.

Delanty, G., 2008, 'Introduction: Migration, discrimination and belonging in Europe', in G. Delanty (ed.), Identity, belonging and migration, pp. 1-20, Liverpoo University Press, Liverpool.

Douglas, M., 1966, Purity and danger: Analysis of concepts of pollution and taboo, Routledge and Kegan Paul, London. http://dx.doi.org/10.4324/9780203361832

Dunn, J., 2005, The new perspective on Paul, Mohr Siebeck, Tubingen.

Frederiksen, P., 2002, 'Judaism, the circumcision of Gentiles, and apocalyptic hope: Another look at Galatians 1 and 2', in M.D. Nanos (ed.), The Galatians debate: Contemporary issues in rhetorical and historical debate, pp. 235-260, Hendrickson, Peabody, MA

Gould, R. \& Watson, P.J., 1982, 'A dialogue on the meaning and use of analogue in ethnoarcheological reasoning', Journal of Anthropological Archaeology 1 , 355-381. http://dx.doi.org/10.1016/0278-4165(82)90002-2

Hall, S., 1997, 'Work of representation', in S. Hall (ed.), Representation: Cultural representation and signifying practice, pp. 13-74, Sage Publication, London.

Hays, R.B., 1996, The moral vision of the New Testament: A contemporary introduction to the New Testament ethics, HarperCollins, New York.

Knudsen, K., 2009, 'Scandinavian neighbours with different characters: Attitudes towards immigrants and national identity in Norway and Sweden', Acta Sociologica 40(3), 223-243. http://dx.doi.org/10.1177/000169939704000301

Lee, T.L.N., 2005, Jews, Gentiles and ethnic reconciliation: Paul's Jewish identity and Ephesians, Cambridge University Press, Cambridge.

Loewe, R., 2008, 'Gentiles as seen by the Jews after CE 70', in W. Horbury \& W.B. Davis (eds.), The Cambridge history of Judaism: Early Roman period, vol. 3 , pp. 250-266, Cambridge University Press, Cambridge.

MacDonald, D. \& Zinyama, L., 2000, 'Guess who is coming to dinner: Migration from Lesotho, Mozambique, Zimbabwe to South Africa', International Migration Review 34(3), 813-841. http://dx.doi.org/10.2307/2675946

McNett, C.W., 1979, 'The cross-cultural method in archaeology', in M.B. Schiffer (ed.), Advances in archaeological method and theory, pp. 41-76, Academic Press, New York.

Nanos, M.D., 2002, 'What was at stake in Peter's "Eating with Gentiles" at Antioch?', in M.D. Nanos (ed.), The Galatians debate: Contemporary issues in rhetorical and historical debate, pp. 282-318, Hendrickson, Peabody, MA.

Meeks, W., 1993, The origin of Christian morality: The first two centuries, Yale University Press, Haven.

Oakman, D., 2001, 'Model and archaeology in the social interpretation of Jesus', in J. Pilch (ed.), Social scientific models for interpreting the Bible: Essays by the context group in honour of Bruce Malina, pp. 102-133, Society of Biblical Literature, Atlanta.

Pattee, S., 1995, 'Paul's critique of Jewship exclusivism: A sociological and anthropological perspective', Sounding: An Interdisciplinary Journal 78 (3/4), 589-610.

Peberdy, S. \& Crush, J., 1998, 'Trading places: Cross-border traders and the South African informal economy', SAMP Migration Policy Series, vol. 6, pp. 1-46, SAMP, Cape Town.

Puskas, C.B., 1989, An introduction to the New Testament, Hendrickson, Peabody.

Sanders, E.P., 2009, Paul, the laws and the Jewish people, Fortress Press, Minneapolis.

Schreiner, T.R., 1991, 'Works of the Law in Paul', Novum Testamentum 33(3), $217-$ 244. http://dx.doi.org/10.1163/156853691X00024

Sloan, R., 1991, 'Paul and the law: Why the law cannot save', Novum Testamentum 33(1), 35-60. http://dx.doi.org/10.1163/156853691X00259

Stewart, E., 2011, 'I'm okay, you're not okay: Constancy of character and Paul's understanding of change in his own and Peter's behaviour', HTS Teologiese Studies/Theological Studies 67(3), Art. \#1002, 8 pages.

Tilly, C., 2005, Identities, boundaries and social ties, Paradigm Publishers, London. 